\title{
Cytotoxic effect of essential oil of thyme (Thymus broussonettii) on the IGR-OV1 tumor cells resistant to chemotherapy
}

\footnotetext{
L. Ait $M^{\prime}$ Barek$^{1}$,

H. Ait Mouse ${ }^{1}$, A. Jaâfari',

R. Aboufatima ${ }^{2}$,

A. Benharref ${ }^{3}$, M. Kamal',

J. Bénard ${ }^{4}$, N. El Abbadi ${ }^{1}$,

M. Bensalah¹, A. Gamouh¹,

A. Chait ${ }^{2}$, A. Dalal ${ }^{2}$ and

A. Zyad ${ }^{1}$
}

\author{
${ }^{1}$ Laboratory of Immunology, Biochemistry and Molecular Biology, Natural Substances, \\ Cellular and Molecular Immuno-pharmacology Group, Faculty of Sciences and \\ Technologies, University Cadi-Ayyad, Béni-Mellal, Morocco \\ ${ }^{2}$ Laboratory of Ecophysiology, ${ }^{3}$ Laboratory of Organic Chemistry and Heterocycles, \\ Faculty of Sciences Semlalia, Marrakech, Morocco \\ ${ }^{4}$ Department of Pathology and Medical Biology, Institute Gustave Roussy, Villejuif, \\ France
}

\author{
Correspondence \\ A. Zyad \\ Laboratory of Immunology, \\ Biochemistry and Molecular Biology, \\ Natural Substances, Cellular and \\ Molecular Immuno-pharmacology \\ Group \\ Faculty of Sciences and Technologies \\ University Cadi-Ayyad \\ Postal Box 523 \\ 23000 Béni-Mellal \\ Morocco \\ Fax: +212-2348-5201 \\ E-mail: ab.zyad@gmail.com
}

Research supported by the PROTARS III D61/07 CNRST, Morocco.

Received January 24, 2007 Accepted July 31, 2007

\begin{abstract}
The anti-tumor effect of the Moroccan endemic thyme (Thymus broussonettii) essential oil (EOT) was investigated in vitro using the human ovarian adenocarcinoma IGR-OV1 parental cell line OV1/P and its chemoresistant counterparts OV1/adriamycin (OV1/ADR), OV1/vincristine (OV1/VCR), and OV1/cisplatin (OV1/CDDP). All of these cell lines elicited various degrees of sensitivity to the cytotoxic effect of EOT. The $\mathrm{IC}_{50}$ values (mean $\pm \mathrm{SEM}, \mathrm{v} / \mathrm{v}$ ) were $0.40 \pm$ $0.02,0.39 \pm 0.02,0.94 \pm 0.05$, and $0.65 \pm 0.03 \%$ for OV1/P, OV1/ ADR, OV1/VCR, and OV1/CDDP, respectively. Using the DBA-2/ P815 $\left(\mathrm{H}_{2} \mathrm{~d}\right)$ mouse model, tumors were developed by subcutaneous grafting of tumor fragments of similar size obtained from P815 (murin mastocytoma cell line) injected in donor mouse. Interestingly, intratumoral injection of EOT significantly reduced solid tumor development. Indeed, by the 30th day of repeated EOT treatment, the tumor volumes of the animals were $2.00 \pm 0.27,1.35 \pm 0.20$, and $0.85 \pm 0.18$ $\mathrm{cm}^{3}$ after injection with 10,30 , or $50 \mu \mathrm{L}$ per $72 \mathrm{~h}$ (six times), respectively, as opposed to $3.88 \pm 0.50 \mathrm{~cm}^{3}$ for the control animals. This tumoricidal effect was associated with a marked decrease of mouse mortality. In fact, in these groups of mice, the recorded mortality by the 30th day of treatment was $30 \pm 4,18 \pm 4$, and $8 \pm 3 \%$, respectively, while the control animals showed $75 \pm 10 \%$ of mortality. These data indicate that the EOT which contains carvacrol as the major component has an important in vitro cytotoxic activity against tumor cells resistant to chemotherapy as well as a significant antitumor effect in mice. However, our data do not distinguish between carvacrol and the other components of EOT as the active factor.
\end{abstract}

Key words

- Essential oil

- Thymus broussonettii

- Ovarian cancer

- Cytotoxicity

- OV1/adriamycin

- OV1/vincristine

- OV1/cisplatin 


\section{Introduction}

Systemic therapy with cytotoxic drugs is the basis of most effective treatments of disseminated cancers. However, the responses of tumors to chemotherapeutic regimens vary, and failures are frequent owing to the emergence of drug resistance. Additionally, the induction of tumor cell resistance to one drug often results in coordinate resistance to other structurally and functionally unrelated drugs, and this defines the multiple drug resistance phenotype $(1,2)$. It is expected that drug resistance may be circumvented by the rational design of new non-cross-resistant agents, by novel delivery or combinations of known drugs and by the development of other treatments that might increase the activity of - or reverse resistance to - known antineoplastic agents $(1,3)$.

The use of medicinal plants for the treatment of diseases is as old as mankind. Essential oils and their components are becoming increasingly popular as naturally occurring bioactive agents (4). Thyme, the most popular medicinal plant in Morocco, has been used in traditional medicine for thousands of years in African and European countries, particularly in the Mediterranean basin (5). Thyme has a wide spectrum of pharmacological properties. In fact, it has been reported that the essential oil of Thymus vulgaris, the most studied species of thyme, has antibacterial, antifungal and antioxidant activities (2,6-12). Additionally, dietary supplementation with thyme oil maintained significantly higher superoxide dismutase and glutathione peroxidase activities and total antioxidant status (13-15). At non-toxic concentrations, thyme extract was also identified as a natural antimutagen with the possibility of enhancement of error-free DNA repair (16). Furthermore, thyme extract has been shown to induce a considerable stimulation of leukopoiesis and also an elevation of thrombocyte count in blood (17). In addition, there is evidence that thymol, a constituent of the essential oil, could be involved in the stimulation of active proliferation of pulp fibroblasts (18). All of these pharmacological activities have been assigned to some widely distributed species of thyme such as $T$. vulgaris, T. zygis and T. satureioides. However, Thymus broussonettii, the endemic Moroccan species, has been poorly studied and there are little data in the literature related to its pharmacological activities due to its very restricted distribution $(19,20)$. Although anti-microbial and anti-inflammatory activities have been described for the essential oil of this species (20), the in vitro and in vivo effects of this natural product on tumor cells have not been described. Given the extensive use of $T$. broussonettii essential oil in Moroccan traditional medicine, and the hypothesis that this essential oil may have anticancer activity $(19,20)$, we decided to examine the in vitro cytotoxic effect of its essential oil against human ovarian adenocarcinoma IGR-OV1 cell lines, both sensitive and resistant to three chemotherapeutic agents used in the treatment of this gynecological carcinoma, i.e., adriamycin (ADR), cisplatin and vincristine (VCR). We also obtained data on the in vivo antitumor activity of this natural extract.

\section{Material and Methods}

\section{Reagents, cell lines and culture conditions}

ADR (doxorubicin), dimethylsulfoxide and crystal violet were purchased from Sigma Chemical Co., Saint Quentin, France. The parental human ovarian adenocarcinoma cell line IGR-OV1 (OV1/P) (21) as well as its counterparts resistant to ADR (OV1/ $\mathrm{ADR}$ ), to vincristine (OV1/VCR) or to cisplatin (OV1/CDDP) (22) were obtained from the Biological Resource Center of Gustave Roussy Institute, Villejuif, France. The murine mastocytoma cell line (P815) was kindly provided by Prof. G. Lemaire, Institute of Biochemistry, University of Paris XI, France. 
These cell lines are routinely cultured in complete medium (Dulbecco's modified Eagle's medium) supplemented with 5\% fetal calf serum (Gibco BRL, Sergy Pontoise, France), $1 \%$ penicillin-streptomycin-neomycin, and $0.2 \%$ sodium bicarbonate (Sigma).

\section{Essential oil extraction}

T. broussonettii was freshly collected in Akrach (the region of Rabat-Zeir, Morocco). The species has been identified and stored as a voucher specimen in the plant collection of Cadi-Ayyad University "HERBIERFSTBM, LT0012". The volatile essential oil of thyme (EOT) was prepared from dried leaves and stems using the hydro-distillation method. The essential oil was then collected after evaporation of the solvent (petroleum ether) under vacuum and stored at $4^{\circ} \mathrm{C}$. Next, the extract was analyzed by gas chromatography/mass spectrometry (GC/MS) using a Thermoquest 2000 GC instrument coupled with a ThermoFinnigan Mass system and a DB-5 capillary column $(0.25 \mathrm{~mm} \times 30 \mathrm{~m} ; 0.25$ mm film thickness; San Jose, CA, USA). Helium was used as the carrier gas. Mass spectra were obtained at $70 \mathrm{eV}$. Mass ranged from $\mathrm{m} /$ z 20-350 amu. Products were identified by comparing their mass spectra with those of a data base (Main lib, Wiley 7, PMW). The injector temperature is set at $250^{\circ} \mathrm{C}$.

\section{Measurement of cytotoxicity mediated by the essential oil of $T$. broussonettii}

This determination was performed as previously described by Zyad et al. (23,24) Briefly, tumor cells were trypsinized $(0.15 \%$ trypsin and $0.1 \%$ EDTA) and 1-1.5 x $10^{5}$ cells $/ \mathrm{mL}$ were incubated in flat-bottom 96 well microtiter plates (Bioster, Bastia di Rovolon, Italy) in $100 \mu \mathrm{L}$ complete medium. Appropriate dilutions of EOT were carried out in culture medium before their addition to the cultured cells (final volume of 100 $\mu \mathrm{L})$. Cells were then incubated for $48 \mathrm{~h}$ in a humidified atmosphere at $37^{\circ} \mathrm{C}$ and $5 \% \mathrm{CO}_{2}$. This incubation time was determined using a kinetic study of EOT-induced cytotoxicity against the OV1/P cell line. After incubation, the medium was carefully removed and replaced with $100 \mu \mathrm{L} 0.5 \%$ crystal violet solution. After $10 \mathrm{~min}$ at room temperature, the plates were washed and viable crystal violet-stained cells were lysed with a $1 \%$ SDS solution. Absorbance was then measured in each well at a wavelength of $540 \mathrm{~nm}$ using a Multiscan instrument (Labsystem, Helsinki, Finland). With this colorimetric procedure, the cytotoxic effects of EOT and ADR could be measured compared to the viability of untreated cells according to the following calculation: $\%$ cell killing $=100 \mathrm{x}$ (1- $A_{t} / A_{o}$ ), where $A_{o}$ and $A_{t}$ are the absorbance values obtained for untreated and EOTor ADR-treated cells, respectively.

\section{Solid tumor induction and treatment in mice}

DBA-2 $\left(\mathrm{H}_{2}{ }^{\mathrm{d}}\right)$ mice purchased from the animal breeding center of Orleans (France) were maintained under specific pathogen-free conditions on a 12-h lightdark cycle. Mice were provided with sterile food and water ad libitum, and were used at 6 to 8 weeks of age with an average weight of $20 \mathrm{~g}$. A primitive syngeneic tumor graft was induced after subcutaneous injection of $5 \times 10^{6}$ cells of the mastocytoma cell line P815 $\left(\mathrm{H}_{2}^{\mathrm{d}}\right)$ in 6- to 8-week-old mice. When the primitive tumor reached a palpable volume, the donor mouse was sacrificed and the tumor was mechanically dissociated. Mice were then subcutaneously grafted with tumor fragments of similar size. Treatment of mice was started when a palpable syngeneic tumor graft had reached a volume of approximately $100 \mathrm{~mm}^{3}$. Three lots of 6 mice each including controls were assigned to each treatment group. These mice were treated with PBS (group A) as negative control, or EOT $(10 \mu \mathrm{L}$ per mouse for group $\mathrm{B}, 30 \mu \mathrm{L}$ per mouse for group $\mathrm{C}$, and 
Table 1. Composition of the essential oil of Thymus broussonettii and gas chromatography retention times.

\begin{tabular}{|c|c|c|}
\hline Component & Retention time (min) & Percentage \\
\hline Camphen & 5.66 & trace \\
\hline B-pinene & 6.31 & $0.79 \%$ \\
\hline Geraniol formate & 6.59 & $0.38 \%$ \\
\hline 1-octen-3-ol & 6.81 & $0.11 \%$ \\
\hline p-menth-1,4(8)-diene & 7.30 & $0.37 \%$ \\
\hline p-cymene & 7.50 & $3.69 \%$ \\
\hline p-metha-1,8-diene & 7.63 & trace \\
\hline$\gamma$-terpinene & 8.46 & $1.86 \%$ \\
\hline 4-isopropyl-1M-2cyclohexane-1-ol & 8.79 & $0.14 \%$ \\
\hline Epoxylinalol & 8.90 & trace \\
\hline B-linalool & 9.80 & trace \\
\hline Terpendiol & 9.89 & $0.70 \%$ \\
\hline Terpinene-1-ol & 10.44 & trace \\
\hline$\sigma$-3-carene & 10.99 & trace \\
\hline Camphor & 11.06 & trace \\
\hline Trans-2-carene-4-ol & 11.17 & - \\
\hline Terpineol-6- $ß$ & 11.29 & - \\
\hline Isoborneol & 11.55 & trace \\
\hline Borneol & 11.94 & $0.41 \%$ \\
\hline 4-terpineol & 12.20 & $0.79 \%$ \\
\hline Linalyl propionate & 12.65 & $0.34 \%$ \\
\hline Isobornyl formate & 13.73 & trace \\
\hline Carvacrol methyl ether & 14.20 & $0.26 \%$ \\
\hline Carvenone & 14.65 & trace \\
\hline Bornyl acetate & 15.59 & trace \\
\hline Thymol & 15.75 & $0.83 \%$ \\
\hline Carvacrol & 16.20 & $83.18 \%$ \\
\hline Cinerone & 17.72 & $0.29 \%$ \\
\hline Thujol & 18.45 & trace \\
\hline$\alpha$-copaene & 18.52 & trace \\
\hline B-bourbounene & 18.81 & - \\
\hline Alloromadandrene & 19.58 & trace \\
\hline Transcaryophyllene & 19.88 & $1.75 \%$ \\
\hline$\alpha$-caryophyllene & 20.91 & trace \\
\hline$\alpha$-muolene & 21.59 & trace \\
\hline B-cadrene & 22.71 & $0.30 \%$ \\
\hline$\alpha$-cadinene & 22.98 & trace \\
\hline Caryophyllene oxide & 24.73 & $0.47 \%$ \\
\hline Germacrene D & 26.33 & trace \\
\hline Murolol & 26.70 & trace \\
\hline Isoaromadandrene epoxyde & 27.15 & trace \\
\hline Trans-1,2-diphenylcyclobutane & 29.21 & - \\
\hline
\end{tabular}

The essential oil was prepared as described in Material and Methods. The qualitative and quantitative composition was determined by gas chromatography/mass spectrometry using a Thermoquest 2000 GC instrument coupled with a ThermoFinnigan Mass system and a DB- 5 capillary column $(0.25 \mathrm{~mm} \times 30 \mathrm{~m} ; 0.25 \mathrm{~mm}$ film thickness). Helium was used as the carrier gas. Mass spectra were obtained at $70 \mathrm{eV}$. Mass ranged from $\mathrm{m} / \mathrm{z}$ 20-350 amu. Products were identified by comparing their mass spectra with those of a data base (Main lib, Wiley 7 , PMW). The injector temperature was set at $250^{\circ} \mathrm{C}$. Trace $=$ less than $0.1 \%$.
$50 \mu \mathrm{L}$ per mouse for group D). These volumes were injected into DBA-2-bearing mice inside the tumor itself (3) at days $0,3,6,9$, 15 , and 18 . Thereafter, the tumor length and width were measured carefully with a caliper every $72 \mathrm{~h}$ for a period of 30 days and the tumor volume was calculated as described by Yoshikawa et al. (25) using the following calculation: Tumor volume $=\mathrm{D} \mathrm{x} \mathrm{d}^{2} / 2$, where "D" and "d" represented tumor length and tumor width expressed in $\mathrm{cm}$, respectively.

\section{Statistical analysis}

Data are reported as means \pm SEM. Statistical differences between the experimental groups were assessed by analysis of variance, with the level of significance set at $\mathrm{P}<$ 0.05 .

\section{Results}

\section{Chemical composition of the essential oil of T. broussonettii}

The chemical composition of the essential oil of $T$. broussonettii determined by GC/MS is shown in Table 1. The oil contains 18 compounds with amounts up to $0.1 \%$ and 20 compounds present only in traces (less than $0.1 \%$ of the total extract). Among these components, carvacrol is the major one, representing $83.18 \%$ of the total extract. Pcymene, $\gamma$-terpinene and transcaryophyllene represent $3.69,1.86$, and $1.75 \%$, respectively, of the total extract.

\section{In vitro cytotoxic effect of the essential oil of T. broussonettii on ovarian tumor cells}

The cytotoxic effect of EOT was evaluated in vitro on the parental cell line, OV1/P, as well as its resistant variants OV1/ADR, OV1/VCR and OV1/CDDP. Figure 1 shows the kinetics of cytotoxicity of various concentrations ( $\mathrm{v} / \mathrm{v})$ of EOT against the parental cell line OV1/P. The cytotoxic activity be- 
gins at $3 \mathrm{~h}$ of incubation and increases in a dose- and time-dependent manner. The optimal incubation time was $48 \mathrm{~h}$, which showed a cytotoxicity comparable to that obtained at $72 \mathrm{~h}$. Thus, in all the subsequent experiments, the incubation time was fixed at $48 \mathrm{~h}$. Figure 2 shows the effect of essential oil on the parental cell line as well as its resistant counterparts. The figure shows that these cell lines present different degrees of sensitivity to EOT. In fact, the concentrations leading to $50 \%$ cytotoxicity $\left(\mathrm{IC}_{50}\right)$ were about $0.40 \pm 0.02,0.39 \pm 0.02,0.65 \pm 0.03$, and $0.94 \pm 0.05 \%$ for OV1/P, OV1/ADR, OV1/ CDDP, and OV1/VCR, respectively. The difference between OV1/CDDP or OV1/ VCR and OV1/P was statistically significant $(\mathrm{P}<0.05)$; however, no difference in EOT cytotoxicity was observed between OV1/P and OV1/ADR.

\section{Effect of the essential oil of $T$. broussonettii on solid tumors in mice}

The in vivo effect of EOT on tumor volume is shown in Figure 3. As can be seen in this figure, the in situ administration of EOT inhibited tumor proliferation in a dose-dependent manner. In fact, by the 30th day of treatment, the tumor volume per mouse (group A) was $3.88 \pm 0.50 \mathrm{~cm}^{3}$ in the control group, as opposed to $2 \pm 0.27,1.35 \pm 0.20$, and $0.85 \pm 0.18$ for the treated groups $\mathrm{B}, \mathrm{C}$, and $\mathrm{D}$, respectively. This effect was statistically significant (ANOVA) when compared to the control group (A) with $\mathrm{P}=0.016$, 0.0014 , and 0.0003 for groups B, C, and D, respectively. The difference between treated groups was also analyzed (ANOVA) and showed that the treatment of group $\mathrm{D}$ was more efficient than that of groups $\mathrm{B}(\mathrm{P}=$ $0.0022)$ and $\mathrm{C}(\mathrm{P}=0.064)$.

\section{Effect of the essential oil of T. broussonettii on mouse survival}

To establish the relationship between the

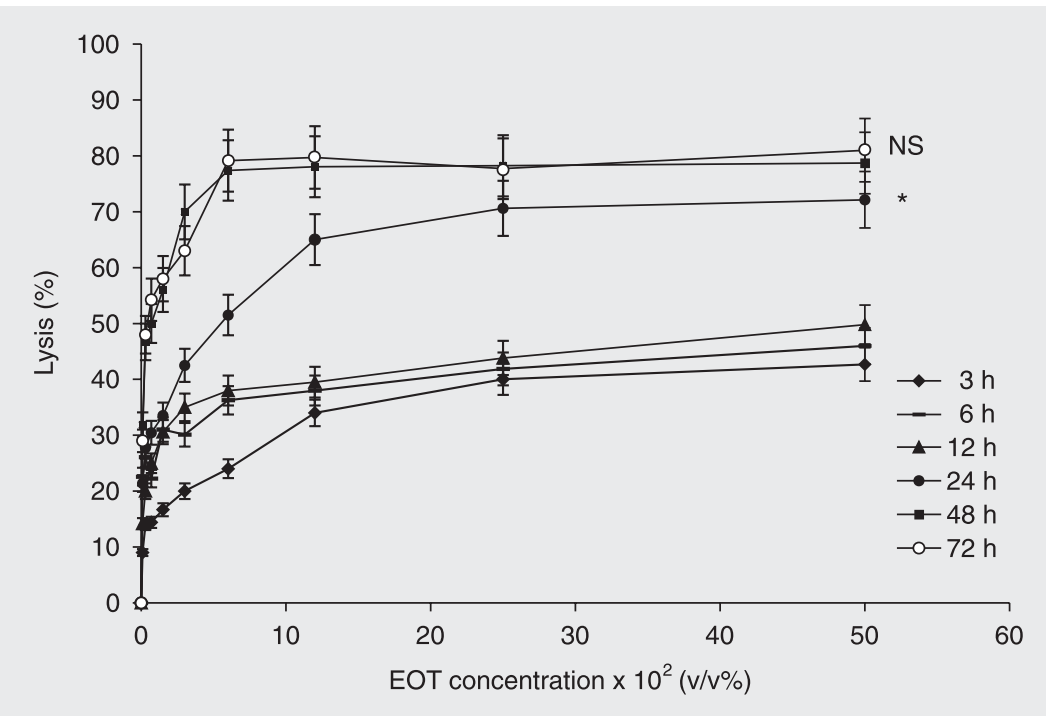

Figure 1. Kinetics of the in vitro cytotoxic activity of the essential oil of Thymus broussonettii (EOT) on the OV1/P cell line. Cells $(105 / \mathrm{mL})$ were treated with increasing concentrations of EOT. After 3, 6, 12, 24, 48, and $72 \mathrm{~h}$ of incubation, cell lysis was determined as described in Material and Methods. Data are reported as the mean \pm SEM of three independent experiments. The differences are assessed comparatively to the values of cytotoxicity at 48 h (ANOVA): ${ }^{*} \mathrm{P}<0.05$; NS = non-significant.

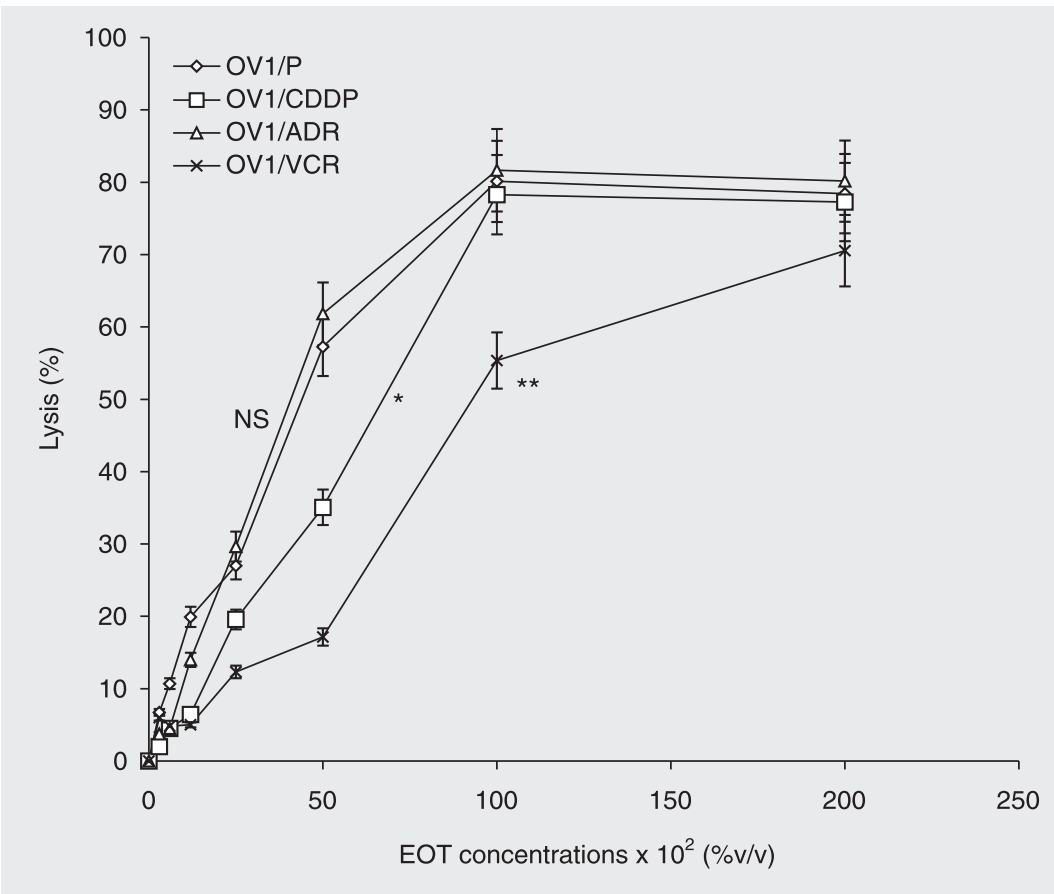

Figure 2. In vitro cytotoxic effect of the essential oil of Thymus broussonettii (EOT) on tumor cell lines. Cells $\left(10^{5} / \mathrm{mL}\right)$ were treated with increasing concentrations of EOT. After $48 \mathrm{~h}$ of incubation, cell lysis was determined as described in Material and Methods. Data are the mean \pm SEM of three independent experiments. NS $=$ non-significant. ${ }^{*} \mathrm{P}<0.05$ and ${ }^{* *} \mathrm{P}<$ 0.01 compared to control (ANOVA). 
Table 2. Effect of the essential oil of Thymus broussonettii (EOT) on the survival of tumor-bearing mice.

\begin{tabular}{lc}
\hline EOT & Mortality \pm SEM (\%) \\
\hline Group A (not treated) & $75 \pm 10 \%$ \\
Group B $(10 \mu \mathrm{L})$ & $30 \pm 4 \%$ \\
Group C $(30 \mu \mathrm{L})$ & $18 \pm 4 \%$ \\
Group D $(50 \mu \mathrm{L})$ & $8 \pm 3 \%$ \\
\hline
\end{tabular}

Tumors (P815) were induced in DBA-2 mice and treated using the protocol described in Material and Methods. During the experiments, all dead mice in each group were recorded and the percentage \pm SEM of the cumulative number at the 30th day is reported.

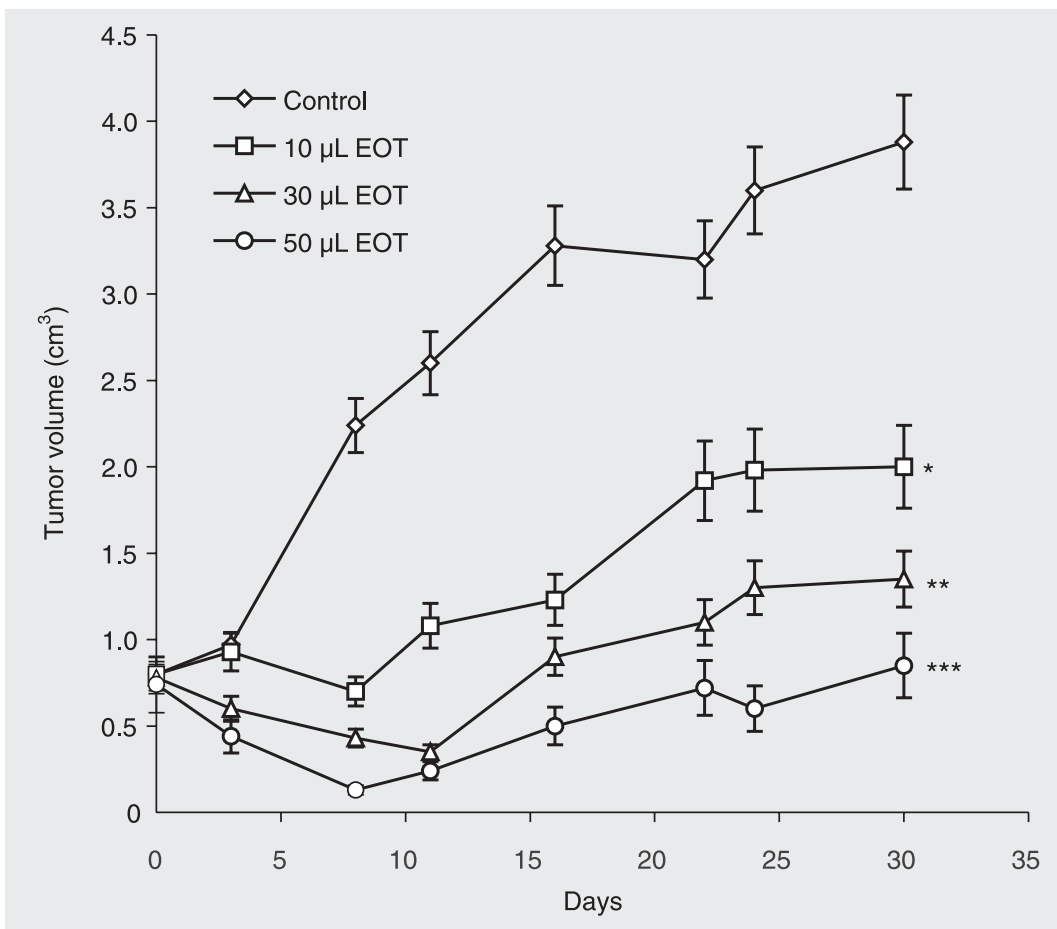

Figure 3. Effect of the essential oil of Thymus broussonettii (EOT) on the evolution of tumor volume in mice. Tumors (P815 murin mastocytoma cells) were induced in DBA-2 mice and treated using the protocol described in Material and Methods. Four groups of six mice each including controls were used. The groups were treated with PBS as negative control or with 10,30 , and $50 \mu \mathrm{L}$ EOT per mouse. After serial injections into the tumor itself of DBA-2 mice at days $0,3,6,9,12,15$, and 18 , the tumor volume of each mouse was measured with a caliper every two days as described in Material and Methods. Data are reported as the mean \pm SEM of three independent experiments. NS = non-significant difference. ${ }^{*} \mathrm{P}<0.05$; ${ }^{* *} \mathrm{P}<0.005$, and ${ }^{* *} \mathrm{P}<0.0005$ compared to PBS control (ANOVA). in vivo antitumor activity of essential oil and mouse survival, the death rate was determined in each group of tumor-bearing mice (Table 2). By the 30th day of treatment, mortality was $8 \pm 3 \%$ in group $\mathrm{D}$, as opposed to $75 \pm 10,30 \pm 4$, and $18 \pm 4 \%$ for groups $\mathrm{A}$, $\mathrm{B}$, and $\mathrm{C}$, respectively.

\section{Discussion}

The present study was performed to provide comparative data on the in vitro cytotoxic activity of $T$. broussonettii essential oil against human ovarian adenocarcinoma cells resistant to chemotherapy and to examine the in vivo anti-tumor efficiency of this natural product. A wide spectrum of pharmacological activities have been described for thyme, such as antioxidant (13), antibacterial $(26,27)$ and antifungal $(28,29)$ properties. These activities have been attributed to some widely distributed species of thyme. However, T. broussonettii, the Moroccan endemic species of thyme, with a very restricted distribution area, has not been sufficiently studied. Given the various uses of the T. broussonettii essential oil in Moroccan traditional medicine and the hypothesis that it may have anticancer activity $(19,20)$, we examined the in vitro cytotoxic effect of this essential oil against the human ovarian adenocarcinoma IGR-OV1 cell line.

Although the difference in sensitivity between OV1/P and OV1/ADR was not statistically significant, the difference between OV1/P and OV1/CDDP or OV1/VCR was significant. However, only low cytotoxicity of EOT has been observed against normal human peripheral blood mononuclear cells (data not shown). The molecular mechanism of the observed cytotoxicity is unknown, but, owing to their lipophilic nature, plant volatile compounds appear to accumulate in the cell membrane and increase its permeability, resulting in leakage of enzymes and metabolites (30,31). Furthermore, thymol and carvacrol have been considered to be the 
principal components responsible for some of the pharmacological activities of thyme essential oil (14,32-34). However, the effect of other components present at lower percentage in the essential oil must be considered. Whether carvacrol alone or in combination with other components of the EOT is responsible for the observed cytotoxicity against ovarian cancer cells remains to be established and is an important limitation of the present study.

In order to determine the in vivo relevance of our in vitro results, we administered the essential oil at the tumor site of tumor-bearing DBA-2 $\left(\mathrm{H}_{2}{ }^{\mathrm{d}}\right)$ mice. This mode of EOT administration was based on a previous study by our group (3) in which we injected different doses of tumor necrosis factor- $\alpha$ and/or ADR into the tumor site of human breast carcinoma-bearing nude mice. This technique was also adopted by Naitoh et al. (35), who reported a significant antitumor effect of intratumoral ethanol injection on renal cell carcinoma in nude rats. This mode of administration is very important since it permits a rapid dissemination of EOT at the tumor site and subsequently a direct contact of tumor cells with this extract. In the present study, the injection of EOT inhibited tumor proliferation in a dosedependent manner while the control group exhibited an increasing tumor volume (Figure 3). By the 30th day of treatment, the tumor volume of control animals was $3.88 \pm$ $0.50 \mathrm{~cm}^{3}$, whereas that of treated animals was $2 \pm 0.27,1.35 \pm 0.20$, and $0.85 \pm 0.18$ $\mathrm{cm}^{3}$ for group B, C, and D, respectively. Our results clearly indicate that the in vivo treatment of tumor-bearing mice with EOT led to the inhibition of tumor proliferation. Furthermore, the incidence of tumor-bearing mouse mortality was delayed by EOT treatment, suggesting that EOT is a very promising natural source of new active principles, which may constitute an attractive new chemotherapy approach to the treatment of cancer.

The present study demonstrated for the first time that ovarian tumor cells and their counterparts resistant to chemotherapy were both affected by EOT. This multicomponent natural product was also effective in inhibiting tumor growth in mice and subsequently in delaying animal mortality. More research is needed to determine the specific components of EOT responsible for these in vitro and in vivo anticancer activities as well as the molecular mechanisms involved in their effects.

\section{Acknowledgments}

The authors thank Prof. Geneviève Lemaire (University of Paris XI, Orsay, France) for her gift of the P815 cell line, Dr. Jacques Couderc (INSERM 131, Cytokines and Immunoregulation, Clamart, France) for his help and Prof. Abdellatif Elmeziane (Cadi-Ayyad University, FST Guéliz, Marrakech, Morocco) for revising the manuscript.

\section{References}

1. Pastan I, Gottesman M. Multiple-drug resistance in human cancer. N Engl J Med 1987; 316: 1388-1393.

2. Gottesman MM, Pastan I. Biochemistry of multidrug resistance mediated by the multidrug transporter. Annu Rev Biochem 1993; 62 : 385-427.

3. Zyad A, Cai Z, Morizet J, Legres LG, Bénard J, Chouaib S. In vivo effect of the combination of TNF and adriamycin against a human breast cell line expressing the MDR-phenotype. Inter J Oncology 1995; 7: 1067-1072.
4. Dursun N, Liman N, Ozyazgan I, Gunes I, Saraymen R. Role of thymus oil in burn wound healing. J Burn Care Rehabil 2003; 24: 395-399.

5. Lai PK, Roy J. Antimicrobial and chemopreventive properties of herbs and spices. Curr Med Chem 2004; 11: 1451-1460.

6. Thuille N, Fille M, Nagl M. Bactericidal activity of herbal extracts. Int $J$ Hyg Environ Health 2003; 206: 217-221.

7. Valero M, Salmeron MC. Antibacterial activity of 11 essential oils against Bacillus cereus in tyndallized carrot broth. Int $J$ Food Micro- 
biol 2003; 85: 73-81.

8. Dragland S, Senoo H, Wake K, Holte K, Blomhoff R. Several culinary and medicinal herbs are important sources of dietary antioxidants. J Nutr 2003; 133: 1286-1290.

9. Kalemba D, Kunicka A. Antibacterial and antifungal properties of essential oils. Curr Med Chem 2003; 10: 813-829.

10. Burt SA, Reinders RD. Antibacterial activity of selected plant essential oils against Escherichia coli O157:H7. Lett Appl Microbiol 2003; 36: 162-167.

11. Fan $M$, Chen J. Studies on antimicrobial activity of extracts from thyme. Wei Sheng Wu Xue Bao 2001; 41: 499-504.

12. Lee KG, Shibamoto T. Determination of antioxidant potential of volatile extracts isolated from various herbs and spices. J Agric Food Chem 2002; 50: 4947-4952.

13. Youdim KA, Deans SG. Dietary supplementation of thyme (Thymus vulgaris L.) essential oil during the lifetime of the rat: its effects on the antioxidant status in liver, kidney and heart tissues. Mech Ageing Dev 1999; 109: 163-175.

14. Tsai PJ, Tsai TH, Yu CH, Ho SC. Evaluation of NO-suppressing activity of several Mediterranean culinary spices. Food Chem Toxicol 2007; 45: 440-447.

15. Youdim KA, Deans SG. Effect of thyme oil and thymol dietary supplementation on the antioxidant status and fatty acid composition of the ageing rat brain. Br J Nutr 2000; 83: 87-93.

16. Vukovic-Gacic B, Simic D. Identification of natural antimutagens with modulating effects on DNA repair. Basic Life Sci 1993; 61: 269277.

17. von Ardenne M, Reitnauer PG. The elevation of the leucocyte and thrombocyte counts produced by a thyme extract in the peripheral blood as compared to that caused by 2-cyanoethylurea (author's transl). Pharmazie 1981; 36: 703-705.

18. Tsukamoto Y, Fukutani S, Takeuchi S, Okamoto T, Mori M. Some phenolic compounds stimulate the proliferation of human pulpal fibroblasts. Shika Kiso Igakkai Zasshi 1989; 31: 357-362.

19. Ismaili $H$, Sosa $S$, Brkic D, Fkih-Tetouani S, Ilidrissi A, Touati D, et al. Topical anti-inflammatory activity of extracts and compounds from Thymus broussonettii. J Pharm Pharmacol 2002; 54: 11371140.

20. Lattaoui N, Tantaoui-Elaraki A. Comparative kinetics of microbial destruction by essential oils of Thymus broussonettii, Thymus zygist and Thymus satureioides. J Essen Oil Res 1994; 6: 165-171.

21. Benard J, Da Silva J, De Blois MC, Boyer P, Duvillard P, Chiric E, et al. Characterization of a human ovarian adenocarcinoma line, IGROV1, in tissue culture and in nude mice. Cancer Res 1985; 45:
4970-4979.

22. Teyssier JR, Benard J, Ferre D, Da Silva J, Renaud L. Drug-related chromosomal changes in chemoresistant human ovarian carcinoma cells. Cancer Genet Cytogenet 1989; 39: 35-43.

23. Zyad A, Branellec D, Mahe Y, Tursz T, Chouaib S. The development of human tumor-cell resistance to TNF-alpha does not confer resistance to cytokine-induced cellular cytotoxic mechanisms. Int J Cancer 1992; 52: 953-958.

24. Zyad A, Benard J, Tursz T, Clarke R, Chouaib S. Resistance to TNF-alpha and adriamycin in the human breast cancer MCF-7 cell line: relationship to MDR1, MnSOD, and TNF gene expression. Cancer Res 1994; 54: 825-831.

25. Yoshikawa T, Kokura S, Tainaka K, Naito Y, Kondo M. A novel cancer therapy based on oxygen radicals. Cancer Res 1995; 55: 1617-1620.

26. Tabak M, Armon R, Potasman I, Neeman I. In vitro inhibition of Helicobacter pylori by extracts of thyme. J Appl Bacteriol 1996; 80: 667-672.

27. Juven BJ, Kanner J, Schved F, Weisslowicz H. Factors that interact with the antibacterial action of thyme essential oil and its active constituents. J Appl Bacteriol 1994; 76: 626-631.

28. Daferera DJ, Ziogas BN, Polissiou MG. GC-MS analysis of essential oils from some Greek aromatic plants and their fungitoxicity on Penicillium digitatum. J Agric Food Chem 2000; 48: 2576-2581.

29. El-Maraghy SS. Effect of some spices as preservatives for storage of lentil (Lens esculenta L.) seeds. Folia Microbiol 1995; 40: 490492.

30. Bard M, Albrecht MR, Gupta N, Guynn CJ, Stillwell W. Geraniol interferes with membrane functions in strains of Candida and Saccharomyces. Lipids 1988; 23: 534-538.

31. Sikkema J, de Boont JA, Poolman B. Mechanisms of membrane toxicity of hygrocarbons. Microbiol Rev 1995; 59: 201-222.

32. Kohlert C, Schindler G, Marz RW, Abel G, Brinkhaus B, Derendorf $\mathrm{H}$, et al. Systemic availability and pharmacokinetics of thymol in humans. J Clin Pharmacol 2002; 42: 731-737.

33. Ultee A, Slump RA, Steging G, Smid EJ. Antimicrobial activity of carvacrol toward Bacillus cereus on rice. J Food Prot 2000; 63: 620624.

34. Mikus J, Harkenthal M, Steverding D, Reichling J. In vitro effect of essential oils and isolated mono- and sesquiterpenes on Leishmania major and Trypanosoma brucei. Planta Med 2000; 66: 366-368.

35. Naitoh Y, Kawauchi A, Mizutani Y, Ukimura O, Fujito A, Nakao M, et al. Significant antitumor effect of intratumoral ethanol injection on renal cell carcinoma. Eur Urol 2003; 44: 452-457. 